\title{
Elevated Insulin-binding Capacity of Serum Pro- teins in a Case with Spontaneous Hypoglycemia and Mild Diabetes Not Treated with Insulin
}

\author{
Yukimasa Hirata and Hiroshi Ishizu \\ The First Department of Internal Medicine, Tottori University \\ School of Medicine, Yonago
}

\begin{abstract}
Hrrata, Y. and Ishizu, H. Elevated Insulin-binding Capacity of Serum Proteins in a Case with Spontaneous Hypoglycemia and Mild Diabetes Not Treated with Insulin. Tohoku J. exp. Med., 1972, 107 (3), 277-286-This report deals with a Japanese male patient who showed severe spontaneous hypoglycemic attacks and mild diabetes. When he was 47-year-old, the first attack of unconsciousness occurred, and after that he was suffering from the same attacks for 5 years. After 3 years from the first attack mild diabetes was found. He was admitted in June, 1968, when he was 52-year-old. Although the patient had never been treated with insulin, his serum showed insulin-binding capacity over 3 years under our observation. A large amount of insulin determined as immunoreactive insulin was extracted with acid ethanol from his native serum. A binding reaction between the insulin-free gamma globulin fraction of the serum and pig 131I-insulin was more inhibited by crystalline human insulin than by crystalline beef insulin. No insuloma was found, but one-third of the pancreas was excised on August 21, 1968. In the histological examination a hyperplasia of the pancreatic islets was significant and there was no inflammatory reactions in the islets. After the operation the hypoglycemic attacks ceased, but the insulin-binding capacity of the serum and mild diabetic state were still observed in July, 1971. - hypoglycemia; pancreatic islets; insulin antibody; diabetes mellitus
\end{abstract}

Insulin antibodies can be demonstrated in man after treatment with pig or beef insulin for 1-2 months. The appearance of insulin antibodies in such diabetics has raised the question whether the pathogenesis of diabetes in some patients may be conditional on the presence of insulin antibodies. This speculation seems attractive and has been alreadly illustrated in the monograph by Jackson (1964). However, in many investigations undertaken with radioactive isotope-labeled insulin as antigen, it was impossible to demonstrate insulin antibodies in all diabetics not treated with insulin.

Concerning hypoglycemia it was suggested by Berson and Yalow. (1957) that hypoglycemia might be unexpectedly caused by release of insulin from antibodycomplexes in the patients who had increased insulin-binding antibodies induced by insulin therapy. It is, therfore, suggested that hypoglycemic attacks may be produced by insulin released from autoimmune antibodies in some cases with

Received for publication, January 7, 1972. 
spontaneous hypoglycemia, although insulin-binding antibodies have never been shown previously in those not treated with insulin.

This report deals with a Japanese male studied for three years who showed severe spontaneous hypoglycemia and mild diabetes. The patient has never been treated with insulin, although his serum showed insulin-binding capacity and contained a large amount of insulin which could be extracted with acid ethanol and determined as IRI (immunoreactive insulin).

\section{Case Report}

A 52-year-old Japanese male was admitted to The Third Department of Internal Medicine of Kyushu University at Fukuoka in June, 1968, for treatment of attacks of unconsciousness and convulsions.

In August, 1963, he had the first attack of unconsciousness after hard exercise during beach-side recreation. After that episode he had similar attacks 4-5 times a year for 2 years. From 1965 the frequency of the attacks increased and he had experienced attacks of unconsciousness and convulsions 3-4 times a month close before the admission. These attacks occurred usually in the early morning.

Mild diabetes was discovered by his home doctor in 1966, characterized by a postprandial glycosuria and a diabetic pattern of blood glucose changes at the glucose tolerance test. The patient and his home doctor reconfirmed that insulin or sulfonylurea therapy had never been instituted before the hospitalization in June, 1968. The patient was a laborer, and he and his family had never received medical educations. Therefore, hypoglycemia factitia due to the use of exogenous insulin must be ruled out in this patient.

In January, 1968, his home doctor found that the unconscious attack responded very rapidly to glucose injection. However, the diagnosis of spontaneous hypoglycemia was not established until June, 1968.

The family history was unremarkable.

Physical examination on admission in June, 1968, revealed a pleasant obese man who was alert and did not appear acutely ill. He did not complain of localizing symptoms, being afebrile, well hydrated and normotensive. In the fundi there was no diabetic retinopathy. The lungs were clear to percussion and auscultation, the heart was not enlarged and no murmurs or friction rub were heard. The abdomen was non-tender, and the liver, spleen and tumors were not palpable.

Laboratory examinations on admission revealed a normal white blood cell count and no anemia. Postprandial glycosuria was found by urinalysis and the total amount of glucose excretion in urine during $24 \mathrm{hr}$ was $5 \mathrm{~g}$. No proteinuria was found and a chest $x$-ray film was normal. Laboratory findings of liver and kidney functions were normal. Serum electrolytes and the amount of total protein and protein fractions of the serum were within normal limits.

After hospitalization the spontaneous hypoglycemic attacks disappeared, although a severe hypoglycemic attack occurred once during a provocation test 
TABLE 1. Diurnal blood glucose changes

\begin{tabular}{|c|c|c|c|c|c|c|c|c|c|c|c|c|c|}
\hline \multirow{3}{*}{$\begin{array}{c}\text { Date of } \\
\text { examination }\end{array}$} & \multicolumn{13}{|c|}{ Blood glucose $(\mathrm{mg} / 100 \mathrm{ml})$ at the times listed below } \\
\hline & \multicolumn{7}{|c|}{ a.m. } & \multicolumn{6}{|c|}{ p.m. } \\
\hline & 0 & 2 & 4 & 6 & 8 & 10 & 12 & 2 & 4 & 6 & 8 & 10 & 12 \\
\hline $\begin{array}{l}\text { July 22, } \\
1968\end{array}$ & 42 & 76 & 64 & & $\begin{array}{c}72 \\
\uparrow \\
\text { eak } \\
\text { A.I }\end{array}$ & $\begin{array}{l}171 \\
t\end{array}$ & $\begin{array}{r}\mathbf{1 3 4} \\
\uparrow \\
\text { Lund } \\
12 \mathrm{~A} .\end{array}$ & $\begin{array}{l}240 \\
\text { L.) }\end{array}$ & 112 & $\begin{array}{r}\quad 36 \\
\uparrow \\
\text { Suppe } \\
6 \mathrm{6} . \mathrm{n}\end{array}$ & 121 & 99 & 72 \\
\hline $\begin{array}{l}\text { October 11, } \\
1968\end{array}$ & 48 & 53 & 66 & & a.n & $\begin{array}{l}252 \\
\mathrm{t}\end{array}$ & $\begin{array}{r}157 \\
\uparrow \\
\text { Lun } \\
(12 \mathrm{a} .\end{array}$ & $\begin{array}{l}224 \\
\text { 1.) }\end{array}$ & 136 & $\begin{array}{c}194 \\
\hat{\uparrow} \\
\text { Supp } \\
\text { (5 p.n }\end{array}$ & 88 & 96 & 48 \\
\hline
\end{tabular}

TABLE 2. Glucose tolerance test

\begin{tabular}{|c|c|c|c|c|c|c|c|c|c|}
\hline \multirow{2}{*}{ Date } & \multirow{2}{*}{ Examination } & \multicolumn{8}{|c|}{$\begin{array}{l}\text { Values obtained at the times listed below } \\
\text { after glucose administration (min) }\end{array}$} \\
\hline & & 0 & 30 & 60 & 90 & 120 & 180 & 240 & 300 \\
\hline \multirow{2}{*}{$\begin{array}{l}\text { July } 11 \\
1968^{*}\end{array}$} & $\begin{array}{l}\text { Blood } \\
\text { glucose }\end{array}$ & 80 & 167 & 218 & & 270 & & & \\
\hline & $\begin{array}{l}\text { Serum } \\
\text { insulin }\end{array}$ & 2,220 & 2,320 & & & & & & \\
\hline \multirow{2}{*}{$\begin{array}{l}\text { October 14, } \\
1968^{*}\end{array}$} & $\begin{array}{l}\text { Blood } \\
\text { glucose }\end{array}$ & 102 & 237 & 322 & 357 & 350 & 180 & 95 & 38 \\
\hline & $\begin{array}{l}\text { Serum } \\
\text { insulin }\end{array}$ & 1,240 & 1,920 & 2,320 & 3,000 & & & & \\
\hline \multirow{2}{*}{$\begin{array}{l}\text { July } 13 \\
1970 \dagger\end{array}$} & $\begin{array}{l}\text { Blood } \\
\text { glucose }\end{array}$ & 117 & 205 & 246 & & 184 & 93 & & \\
\hline & $\begin{array}{l}\text { Serum } \\
\text { insulin }\end{array}$ & 274 & 400 & 520 & & 520 & 580 & & \\
\hline \multirow{2}{*}{$\begin{array}{l}\text { July 5, } \\
1971 \uparrow\end{array}$} & $\begin{array}{l}\text { Blood } \\
\text { glucose }\end{array}$ & 116 & 224 & 256 & & 224 & 147 & & \\
\hline & $\begin{array}{l}\text { Serum } \\
\text { insulin }\end{array}$ & 288 & 300 & 360 & & 436 & 480 & & \\
\hline
\end{tabular}

Blood glucose: $\mathrm{mg} / 100 \mathrm{ml}$, Serum insulin: $\mu \mathrm{U} / \mathrm{ml}$

* $100 \mathrm{~g}$ glucose tolerance test $† 50 \mathrm{~g}$ glucose tolerance test

with tolbutamide. The glucose levels of the venous blood determined repeatedly with the glucose oxidase method ranged from 51 to $95 \mathrm{mg} / 100 \mathrm{ml}$ before breakfast in the morning. Diurnal blood glucose changes were characterized by a wide fluctuation from severe hypoglycemia to remarkable hyperglycemia as shown in Table 1. A diabetic pattern of blood glucose changes was shown by the standard glucose tolerance test before and after the operation performed on August 21, 
1968. In this operation about one- third of the pancreas was excised, thereafter spontaneous hypoglycemic attacks have not been observed for 3 years. The glucose tolerance test with $50 \mathrm{~g}$ of glucose carried out in July of 1970 and 1971 demonstrated again a diabetic pattern as shown in Table 2.

He is now 55-year-old, still obese and remains free of attacks of unconsciousness or convulsions. He has never received insulin injection at least from the time of the admission in June, 1968.

In the procedure to determine serum insulin, an extraction procedure with acid ethanol was necessary since insulin-binding capacity was found in the serum of this patient. The actual insulin levels were significantly higher than normal levels; about 100 times of the fasting normal level in 1968 and 1969, and about 10 times in 1970 and 1971.

\section{METHODS}

\section{Measurement of the circulating insulin.}

Measurement of the circulating insulin was done by the immunoassay using a single antibody system; the ethanol precipitation method of Heding modified by us (Nakamura et al. 1972). The immunoassay was carried out after initial extraction of serum aliquots with acid ethanol which eliminated insulin antibodies. The extraction procedure of Grodsky and Forsham (1960) was employed in our study.

\section{Analysis of insulin in the serum}

Gel filtration procedures were employed for the analysis of insulin in the serum. The gel filtration was carried out on Sephadex G-75 columns $(1 \times 18 \mathrm{~cm})$ or on Sephadex G200 columns $(1 \times 40 \mathrm{~cm})$. The columns were equilibrated and eluted with $0.1 \mathrm{M}$ phosphate buffer. To separate the insulin-protein complexes the gel filtration was carried out on Sephadex G-75 columns $(1 \times 18 \mathrm{~cm})$ equilibrated and eluted with $0.05 \mathrm{M}$ glycine buffer adjusted with $\mathrm{HCl}$ to $\mathrm{pH}$ 3.0. All separated fractions were individually measured for optical density and treated primarily with acid ethanol as described above for the measurement of IRI.

\section{Characteristics of insulin-binding capacity of the serum}

For the demonstration of insulin-binding capacity of the serum proteins, the method of hydrodynamic flow paper chromatography introduced by Berson et al. (1959) was employed. Insulin-free proteins were isolated from the serum by elution on Sephadex G-75 columns equilibrated with glycine buffer at $\mathrm{pH}$ 3.0. The fraction of insulin-free proteins was neutralized by phosphate buffer and mixed with a solution of $25 \% \mathrm{Na}_{2} \mathrm{SO}_{4}$; the ratio of mixing was $1: 1.7$ at $25^{\circ} \mathrm{C}$. The protein precipitates procuced by $\mathrm{Na}_{2} \mathrm{SO}_{4}$ were diluted in saline and $\mathrm{Na}_{2} \mathrm{SO}_{4}$ was eliminated by Sephadex G-75 columns equilibrated by saline. By this procedure the insulin-free gamma globulin fraction was obtained and used to make "standard curves" with tracer porcine ${ }^{131}$ I-insulin and standard crystalline insulins; human insulin (Novo Lot No. 27-3264) and bovine insulin (Novo Lot No. 027667).

\section{Results}

\section{Hydrodynamic flow paper chromatography}

One $\mathrm{ml}$ of the serum of the patient was mixed with $0.025 \mu \mathrm{g}$ of ${ }^{131} \mathrm{I}$-insulin and incubated for $24 \mathrm{hr}$ at $4^{\circ} \mathrm{C}$. In the paper chromatogram after hydrodynamic flow 


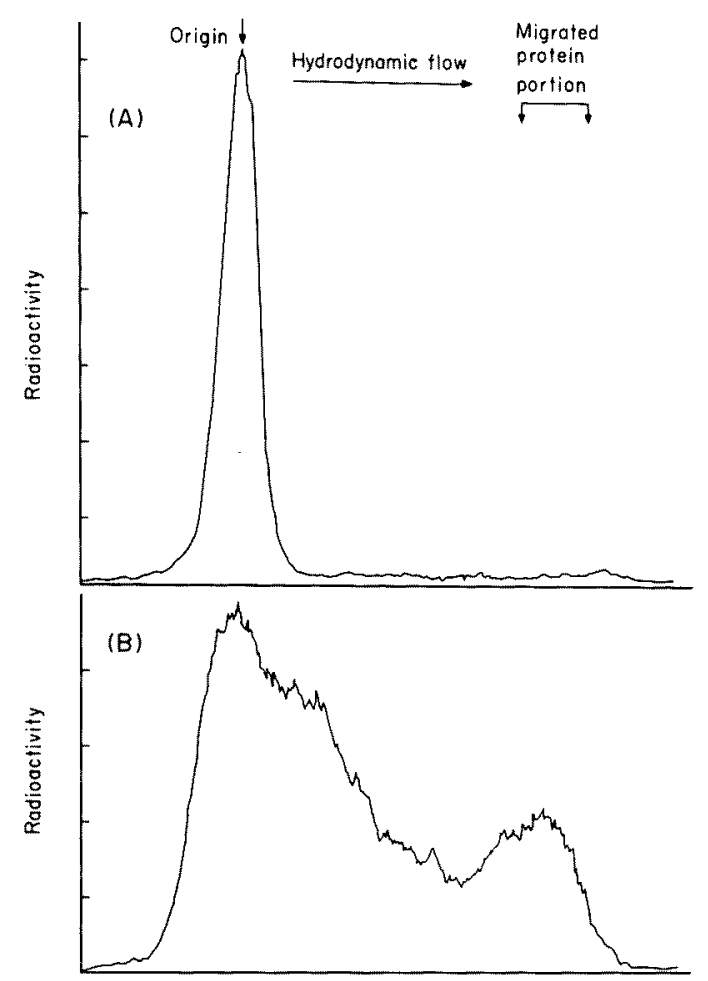

Fig. 1. Hydrodynamic flow paper radio-chromatogram of the mixture of pig ${ }^{131}$ I-insulin with the normal human serum (A) and with the serum of the patient reported in this paper (B).

some portions of added ${ }^{131}$ I-insulin migrated with the proteins as bound insulin. The insulin-binding capacity of the serum of the patient was shown in the serum obtained on July 24, 1968, on July 9, 1969 (Fig. 1), and on July 13, 1970. The separation of free and bound ${ }^{131} \mathrm{I}$-inslin mixed with the serum of this case was not clear, while the separation was much better when ${ }^{131}$ I-insulin was mixed with the sera of patients treated with exogenous insulin.

Insulin concentrations in the serum and relationship between endogenous insulin and insulin-binding capacity of the serum

Serum insulin concentrations, determined as IRI after the extraction procedure with acid ethanol, were between 1,000 and $3,000 \mu \mathrm{U} / \mathrm{ml}$ in 1968 and 1969 . However, the concentrations in the morning before glucose loading decreased to 274 $\mu \mathrm{U} / \mathrm{ml}$ on July 13,1970 , and to $288 \mu \mathrm{U} / \mathrm{ml}$ on July 5,1971 , although these concentrations were still about $10-20$ times higher than the normal levels.

On October 14, 1968, after the oral administration of glucose, insulin concentrations increased from 1,240 to $3,000 \mu \mathrm{U} / \mathrm{ml}$, while the percentage of bound ${ }^{131} \mathrm{I}$-insulin in the untreated serum $\left(0.005 \mu \mathrm{g}\right.$ of ${ }^{131} \mathrm{I}$-insulin to $1 \mathrm{ml}$ of the serum) 


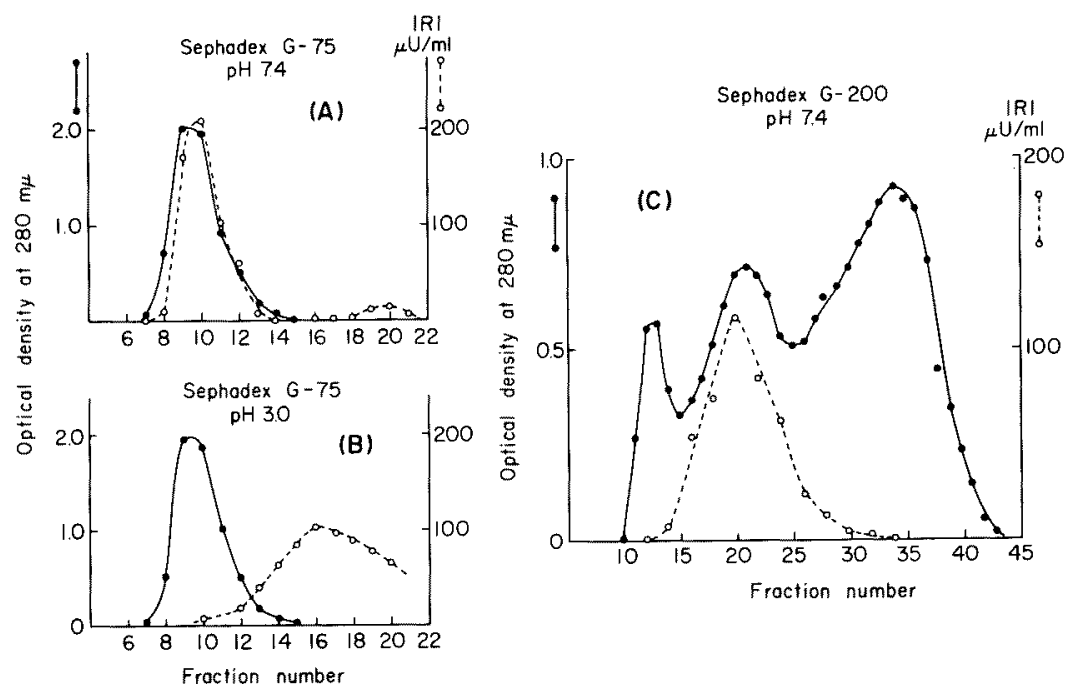

Fig. 2. IRI (immunoreactive insulin) content in the serum proteins of the patient after the gel-filtration. (A) Fractions separated by Sephadex G-75 column at $\mathrm{pH} 7.4$; (B) Fractions separated by Sephadex G-75 column at pH 3.0; (C) Fractions separated by Sephadex G-200 column at $\mathrm{pH} 7.4$.

decreased from $46 \%$ to $30 \%$. Separation of the bound insulin in the latter procedure was carried out with the ethanol precipitation method. This phenomenon seemed to prove that the insulin-binding capacity of this serum was affected by the concentration of endogenous insulin; the increased endogenous insulin could decrease the binding capacity of the serum for exogenous insulin.

\section{State of insulin in the serum}

The serum obtained in the morning of July 11, 1968, was filtered by the Sephadex columns. Almost all insulin in the serum was extracted from the protein portion separated by the Sephadex G-75 column at $\mathrm{pH} 7.4$ (Fig. 2A). Also, the protein-bound insulin was extracted from the globulin fractions separated by the Sephadex G-200 column at $\mathrm{pH} 7.4$ (Fig. 2C). Protein-bound insulin became free insulin by filtration through the Sephadex G-75 column at $\mathrm{pH}$ 3.0 as shown in Fig. $2 \mathrm{~B}$.

\section{Nature of insulin-free globulin fraction of the serum}

Gamma globulin fraction from the patient's serum being filtered through the Sephadex column at $\mathrm{pH} 3.0$ was diluted to make "standard cruves" for the immunoassay of insulin. The dilution rate was adjusted to give the value of bound insulin in the range of about $50 \%$ of added ${ }^{131} \mathrm{I}$-insulin. In the standard curves, the binding reaction between the gamma globulin fraction and pig ${ }^{131}$ Iinsulin was more inhibited by crystalline human insulin than by crystalline beef 
(A)

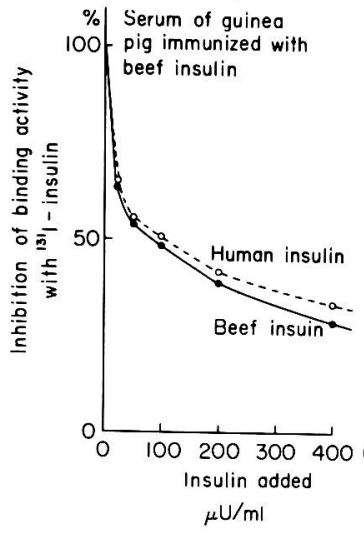

(B)

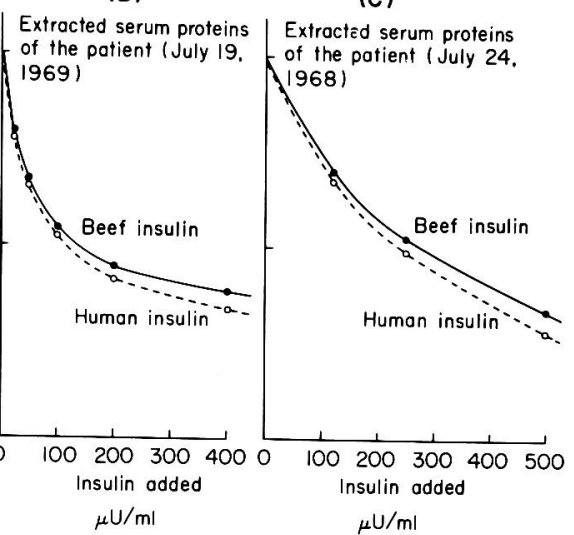

Fig. 3. Inhibition by non-radioactive crystalline human or beef insulin of the binding capacity of the guinea pig antiinsulin serum (A) and of the extracted serum proteins from the patient (B, C) with pig ${ }^{131} \mathrm{I}$-insulin. (B) The serum obtained on July, 1969; (C) The serum obtained on July 24, 1968.

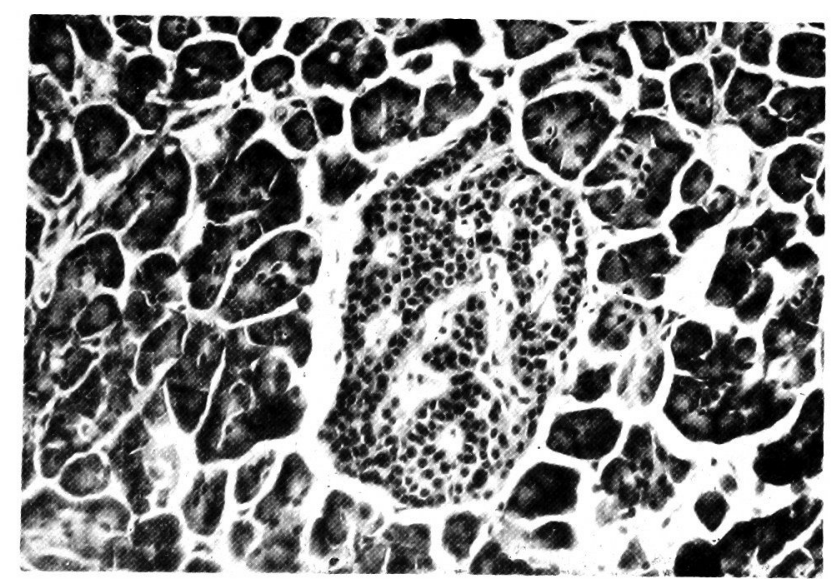

Fig. 4. Pancreatic tissue excised on August 21, 1968. Hematoxylin and eosin stain. Magnification: $\times \mathbf{2 0 0}$.

insulin; that is, antigenicity of human insulin for the extracted gamma globulin of the patient's serum seemed stronger than that of beef insulin. As in the control study the diluted anti-insulin serum of guinea pig immunized with crystalline beef insulin was used for making standard curves. In the latter procedure the antigencity of beef insulin for the diluted guinea pig anti-insulin serum was stronger than that of human insulin (Fig. 3).

\section{Morphological changes of the pancreas}

On August 21, 1968, the pancreas of the patient was examined by laparotomy. It showed a normal size and unremarkable morphological findings; no insuloma 
was found. One-third of the pancreas was excised to prevent the attacks of spontaneous hypoglycemia.

On histological examination hyperplasia of the pancreatic islets was significant, while there were no inflammatory signs in the islets and in the periinsular tissues (Fig. 4).

This patient represents a case of spontaneous hypoglycemia and mild diabetes. Although he had never received exogenous insulin, his serum proteins showed insulin-binding capacity. A large amount of endogenous insulin was extracted from the globulin portion of the serum, and the gamma globulin fraction from the treated insulin-free serum of the patient bound human insulin more strongly than bovine insulin.

Páv et al. (1963) and Chetty and Watson (1965) showed an antibody-like activity by the complement consumption method in diabetic patients not treated with insulin. Chetty and Watson (1965) reported that in non-insulintreated diabetics the complement consumption test was positive in $58 \%$ of the cases, but it was also positive in $26 \%$ of non-diabetics. The complement consumption test seemed to be a non-specific method for the detection of insulin antibodies. Penchev et al. (1968) reported that the precipitation reaction using the agarprecipitation method of Oudin was more often positive in the group of diabetics not treated with insulin, but in our previous experience of the study on insulin precipitating antibodies (Hirata and Blumenthal 1962) non-specific reactions seemed to occur frequently with human serum. Mancini et al. (1965) mentioned that in three diabetics not treated with insulin a gamma globulin fraction was demonstrated which, when labeled with fluorescein isothiocyanate and dripped on to fresh human pancreatic tissure, resulted in fluorescence of beta cells. However, this phenomenon also seems non-specific.

All other studies on insulin-binding capacity of the serum proteins tested with isotope-labeled insulin as antigen have given negative results in the diabetics not treated with insulin, although the binding capacity becomes positive in the serum of patients after treatment with exogenous insulin for several weeks.

It has also been proved possible to immunize pigs, cows, sheep and rats even with species-specific insulin, but the hormone must be injected as exogenous insulin to produce insulin-binding antibodies (Berson and Yalow 1959). The reaction of human insulin with insulin-binding antibodies in the serum of human subjects treated with commerical mixtures of insulins was already demonstrated by Berson and Yalow (1961). They reported that comparison of the binding of human insulin and beef insulin in antiserum from eight insulin-resistant and non-resistant diabetic subjects revealed a lesser affinity of antibody for human than for beef insulin in most cases. They also mentioned that the reaction of human insulin with human antiserums to beef-pork insulin did not, of course, imply that human insulin was antigenic in man.

Grodsky and his colleagues (Grodsky 1965, Grodsky et al. 1966, Karam et al. 1969) demonstrated insulin-binding autoantibodies in man and rabbits. They 
reported that normal rabbits immunized with bovine insulin in adjuvant produced circulating autoantibodies that bound a large amount of endogeneous insulin. In their experiment, in nine immunized animals, two animals not only produced autoantibody, but also, as a result of the autoimmune phenomenon, became acutely diabetic. Both diabetic rabbits showed hydropic degeneration of the ductal epithelium and beta cells of pancreas, also lymphocytic infiltration of the islets was noted in the less severely diabetic animal, but lymphocytes in the islets could not be detected in the more severely diabetic rabbit. It should be mentioned that man and rabbits showing antibodies in the reports of Grodsky and his colleagues had received the injection of heterogenous commerical or crystalline insulin.

There have been a few reports on the existence of a small amount of IRI in gel-filtered serum protein fractions of some animals. Kajinuma et al. (1969) reported such phenomenon in the pancreatic venous serum of dogs not treated with insulin. Konijnendijk and Bouman (1970) studied bovine serum proteins treated with Sephadex G-100, and they emphasized the existence of IRI-like material in globulin fractions; they also pointed out that some $7-10 \%$ of the initial IRI content was eluted in the globulin fractions of the bovine serum to which crystalline insulin had been added. However, in the serum of the patient in our report almost all IRI was extracted from protein fraction which had been separated with Sephadex columns.

Although the patient reported in this paper had never received insulin injection, the gamma globulin fraction extracted from his serum from which insulin was initially eliminated showed a significantly elevated binding capacity with human insulin. This elevated insulin-binding capacity of the serum might stimulate insulin secretion and produce a mild diabetic state, and increased formation of insulinprotein complexes in the serum might be a cause of spontaneous hypoglycemia. In this patient an autoimmune phenomenon was strongly suggested as a cause of the production of insulin-binding proteins in gamma globulin fraction, whereas the pancreas of this case represented non-inflammatory reactions in contrast with those of the rabbits reported by Grodsky and his colleagues, in which autoimmune antibodies in their serum might produce inflammatory reaction around the pancreatic islets. Autoantibodies in the latter rabbits were induced by the administration of exogenous insulin, while the patient in this paper had never received exogenous insulin.

\section{Acknowledgment}

We wish to thank Dr. Solomon A. Berson, Professor of Medicine of The Mount Sinai School of Medicine, for kind suggestions.

\section{References}

1) Berson, S.A. \& Yalow, R.S. (1957) Kinetics of reaction between insulin and insulinbinding antibody. J. clin. Invest., 36, 873-874.

2) Berson, S.A. \& Yalow, R.S. (1959) Species-specificity of human antibeef, pork 
insulin serum. J. clin. Invest., 38, 2017-2025.

3) Berson, S.A. \& Yalow, R.S. (1961) Preparation and purification of human insulin$\mathrm{I}^{131}$; binding to human insulin-binding antibodies. $J$. clin. Invest., 40, 1803-1808.

4) Berson, S.A., Yalow, R.S., Bauman, A., Rothschild, A. \& Newerly, K. (1956) Insulin- $\mathbf{I}^{131}$ metabolism in human subjects; demonstration of insulin binding globulin in the circulation of insulin treated subjects. $J$. clin. Invest., 35, 170-190.

5) Chetty, M.P. \& Watson, K.C. (1965) Antibody-like activity in diabetic and normal serum, measured by complement consumption. Lancet, 1, 67-69.

6) Grodsky, G.M. (1965) Production of antoantibodies to insulin in man and rabbits. Diabetes, 14, 396403 .

7) Grodsky, G.M., Feldman, R., Toreson, W.E. \& Lee, J.C. (1966) Diabetes mellitus in rabbits immunized with insulin. Diabetes, 15, 579-585.

8) Grodsky, G.M. \& Forsham, P.H. (1960) An immunochemical assay of total extractable insulin in man. J. clin. Invest., 39, 1070-1079.

9) Hirata, Y. \& Blumenthal, H.T. (1962) Precipitation of insulin with sera of insulintreated guinea pigs and rabbits. J. Lab. clin. Med., 60, 194211.

10) Jackson, W.P.U. (1964) On Diabetes mellitus, Charles C. Thomas Publisher, Springfield, p. 8 .

11) Kajinuma, H., Ide, T., Kuzuya, T. \& Kosaka, K. (1969) Insulin-like activity by fat pad assay and immunoreactive insulin. II. Their occurrence in fractions by gel filtration of serum. Diabetes, 18, 75-83.

12) Karam, J.H., Grodsky, G.M. \& Forsham, P.H. (1969) Insulin-resistant diabetes with autoantibodies induced by exogenous insulin. Successful treatment by insulin withdrawal. Diabetes, 18, 445-454.

13) Konijnendijk, W. \& Bouman, P.R. (1970) Insulin-like activity and immunoreactive insulin content of gel-filtered protein fractions of bovine serum. Diabetologia, 6, $379-385$.

14) Mancini, A.M., Zampa, G.A., Vecchi, A. \& Costanzi, G. (1965) Histoimmunological techniques for detecting anti-insulin antibodies in human sera. Lancet, 1, 11891191.

15) Nakamura, Y., Hirata, Y., Nishimura, H. \& Fujisawa, M. (1972) Radioimmunoassay of plasma insulin using ethanol precipitation of insulin-antibody complex. $J . J a p$. Diab. Soc. (Jap.), 15, 18-23.

16) Páv, J., Ježková, Z. \& Șkrha, F. (1963) Insulin antibodies. Lancet, 2, 221-222.

17) Penchev, I., Andreev, D. \& Ditzov, S. (1968) Insulin-precipitating antibodies in insulin-treated and untreated diabetic patients. Diabetologia, 4, 164-166. 